\title{
WHAT WERE THE SADDUCEES READING? AN ENQUIRY INTO THE LITERARY BACKGROUND OF MARK 12:18-23
}

\author{
Peter G. Bolt
}

\section{Summary}

Where did the Sadducee's case study (Mk. 12:20-23) originate? After dismissing 2 Maccabees 7, this article suggests that the Book of Tobit most probably provides the Sadducees with their story. Both they and Tobit talk of the death of 7 husbands and Levirate marriage in the context of an interest in resurrection. The article ends by suggesting that this allusion to Tobit may bring further nuances to the reading of the Gospel of Mark.

In the midst of the controversies of Mark 12, the Sadducees question Jesus about the resurrection (Mk. 12:18-27), something to which, as Mark informs his readers (v. 18), they were not committed. 1 Through the citation of Scripture (v. 19, cf. Dt. 25:5-6) and the application of a case-study (vv. 20-23) they attempt to ridicule the notion of resurrection. In their view, the case study demonstrates the absurdity of a resurrection, since it conflicts with the Mosaic law of Levirate marriage, ${ }^{2}$ for 'in the resurrection, whose wife will she be?' (v. 23).

${ }^{1}$ This standard New Testament picture of the Sadducees as denying the resurrection (cf. Acts 23:6-8, and the Markan parallels Mt. 22:23, Lk. $20: 27$ ) is confirmed by Josephus ( $A J 18.1,4 ; B J$ 2.8.14 $\$ 165$ ). The Mishnah evidently associates the Sadducee with the Epicurean philosophy due to this denial (Sanh. x.1, Gem. 90a, Sifre [Num. 112]), see G. Deutsch, 'Apikoros', J.Enc (New York: Funk \& Wagnall, 1901, 1925) I.665-666.

2Gould, Mark (Edinburgh, 1912) 228, suggests that they make the point that the law allows for these successive marriages which the resurrection would make simultaneous. Could the same law teach both things? Cf. Nineham, Mark (Harmondsworth, 1963) 319. 
It is not common to inquire into the origin of the 'case study' which is so crucial to the Sadducees' argument. Was it simply a 'made-up story', ${ }^{3}$ an hypothetical case? ${ }^{4}$ Were they making use of a case actually discussed by their Pharisaic opponents, 5 and, if so, where did this particular case originate? Was it 'the standard puzzle of the Sadducees, in which they sought to discredit the resurrection by reducing it to an absurdity'? ${ }^{6}$ If so, why this puzzle? Where did it come from?

It is the intention of this article to suggest that the Sadducees may have been drawing upon a well-known story, no doubt favoured by the Pharisees, in order to make their point all the more forcibly. After (I) a preliminary discussion of the potential influence of the story of the seven Maccabean martyrs, I will argue (II) that the book of Tobit provides a more probable background. Returning to the Sadducees' question (III), I will suggest that this literary background may import some rich connotations into Mark's account of this controversy story. Given the importance of intertextuality to the reading of a text, this observation will have implications for the reading of this incident in its literary context within Mark's Gospel.

The case study is introduced simply by 'there were

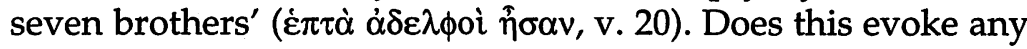
known literary connections? Two possibilities spring to mind.

3'ersonnene Geschichte', Pesch, Markus-Evangelium (Freiburg, 1977) II.230, quoting Lohmeyer, Mark, 255; cf. 'the case looks contrived', Gundry, Mark (Grand Rapids, 1993) 701.

4So Anderson, Mark (London, 1976) 276; Barnett, The Servant King (Sydney, 1991) 239; Cole, Mark (Grand Rapids, 1961) 189, a 'man of straw'; Wessel, 'Mark', Expositors Bible Commentary (Grand Rapids, 1984) vol. 8:735. Cf. Hooker, Mark (London, 1991) 283, 'the number [7] is typical of such stories'.

${ }^{5}$ Anderson, Mark, 278, who provides no further details. Branscombe, Mark (London, 1937) 217, likewise appears to regard it as a real case. Swete, Mark (London, 1908) 29, points out that this is the impression given by Mt. 22:25, although, given my arguments below, the 'among us' may not imply contemporaneity, but could equally mean 'as part of our tradition/history'.

${ }^{6}$ Gould, Mark, 228. The recognition that it is an argument ad absurdum avoids the mistake that this is a Pharisaic question regarding the manner, rather than the fact of the resurrection. 


\section{The Seven Maccabean Martyrs}

It is not unreasonable to suggest that this simple reference to seven brothers could have been enough to evoke immediately the moving story of the Maccabean martyrs for any who knew

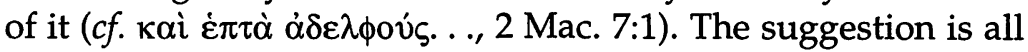
the more plausible given that the Sadducees intend to ridicule the notion of resurrection and the story of the martyrs is one in which the belief in the resurrection from the dead is clearly and heroically expressed (cf. vv. 9, 11, 14, 23, 28-29, 36). ${ }^{7}$ Both stories contain the notion of a woman receiving back her dead in the resurrection. Although this is in terms of a mother receiving her sons in Maccabees (2 Mac. 7:29), rather than a wife receiving her previous husbands as in the Sadduceean story, it could be argued that it is a small step from the one to the other.

The story of the Maccabean martyrs was certainly influential. The author of second Maccabees himself presumably reissues it (in abridged form?) from the five volume account of Jason of Cyrene (2 Mac. 2:19ff.). ${ }^{8}$ Its influence stretched beyond the period relevant for our inquiry, inspiring Jewish and Christian reflections well into the Middle Ages. ${ }^{9}$ The fact that the first-century work, 4 Maccabees, 10 chose to elaborate upon the story of the seven martyrs may indicate the popularity and emotional appeal of this story even during Jesus' time, ${ }^{11}$ especially given any analogies that may have

72 Maccabees' interest in resurrection is also brought in the description of Judas, 2 Mac. 12:43ff.

${ }^{8}$ 'The popularity of the Epitomist's work is attested by the loss to posterity. of Jason's original five-volume history and the continued circulation of the digest. The Greek text of the latter was subsequently translated into Latin, Syriac, Coptic, and Armenian,' B.M. Metzger, An Introduction to the Apocrypha (New York: Oxford University Press, 1957) 141.

9See G.D. Cohen, 'Hannah and her Seven Sons', EncJ 7:1270-71; Y. Amir, 'Maccabees, Fourth Book of', EncJ 11:662; T.W. Manson, 'Martyrs and Martyrdom', BJRL 39 (1956-57) esp. 479-84.

10J.A. Goldstein, II Maccabees (AB 41A; New York: Doubleday, 1983) 26, dates it between 18 and 55 C.E.

${ }^{11}$ The case for the currency of the story may be further strengthened the closer the composition date of 2 Maccabees comes to the first century 
been drawn between Roman and Epiphanian domination.12 Although it is impossible to tell whether the author of 2 Maccabees-or Jason of Cyrene-was himself a Pharisee, ${ }^{13}$ in view of its heroic support of resurrection belief, it seems reasonable to assume that the story was a particular favourite amongst the Pharisees.

If the Sadducees have this story in mind, they are perhaps adapting a favoured story of their Pharisaic opponents (with whom they evidently identify Jesus) in order to serve their own ends by reducing its' substance to absurdity. This would be a particularly cruel ploy, given the emotional associations that the Pharisees would have attached to the martyrs and their cause. Their deaths were not only noble examples of how they suffered rather than saving their own souls ( $c f$. Eleazer's death 2 Mac. 6:28, 30, 31), but were for the discipline rather than the destruction of the nation (2 Mac. 6:12), and so they were regarded implicitly as the sacrifice of the nation ( $c f .2$ Mac. 6:1).14 Being thus typological of Israel,

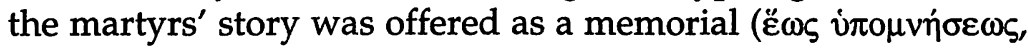
2 Mac. 6:17). ${ }^{15}$ The Sadducees' ridicule of the Pharisaic

(Goldstein, Maccabees, 83, dates it between 78/7-63 B.C.E.). Placing it during the reign of Agrippa I (41-44 C.E.), as proposed by S. Zeitlin, The Second Book of Maccabees (S. Tedesche, transl.; New York: Harper \& Brothers, 1954) 27-31, would indicate the continued influence of Jason's version.

${ }^{12}$ 'Clearly [4 Maccabees] is intended to persuade and move its readers to consider the virtuous Jews as models for their own attitudes toward unjust rulers (cf. 18:1-2). If it was composed in the mid-first century, then the increasing tensions with Rome, at least in Palestine, would have given the accounts contemporary relevance,' R.D. Young, 'The "Woman with the Soul of Abraham": Traditions about the Mother of the Maccabean Martyrs', "Women Like This". New Perspectives on Jewish Women in the Greco-Roman World (A.-J. Levine, ed.; Atlanta: Scholars, 1991) 73.

13Y.M. Grintz, 'Maccabees, Second Book of', EncJ 11: 659; U. Rappaport, 'Jason of Cyrene', EncJ 9: 1291.

${ }^{14}$ The final brother 'recalls the Law of Moses, the covenant with Abraham and the promise of resurrection which by now it is understood to entail, and he casts the children's deaths in sacrificial terms,' Young, '“Woman"', 72.

15Young, "Woman"', 69. 
resurrection faith through the vehicle of such a story would be an horrendous tactic.

Such a background would help to explain why Jesus' reply appears so abrupt (Mk. 12:24a, 27b) towards those who appear to take Israel's theological heritage so lightly. It is also interesting that the account of the martyrs in 4 Maccabees has an affinity with Jesus' reply, in that they strengthen each other with the hope that, if they die, the patriarchs Abraham, Isaac and Jacob will welcome them (4 Mac. 13:17, cf. Mk. 12:26).

However, apart from the number of brothers, and the association with the resurrection, there are not many other links between these stories. Perhaps the fatal difference between the two is the lack of any reference to marriage in the Maccabean tale; after all, a mother of seven is not a wife of seven; a martyrdom is not a marriage. Although the story and all its connotations may still be evoked to some degree for the discerning hearer, perhaps the Sadducees' case study is derived from another place.

\section{Tobit}

After stating that the 'seven' is simply a round number, Pesch commends the consideration of the possibility that the story may have been inspired by the Book of Tobit, although he does not take this suggestion any further himself.16 Lane also endorses the possibility that 'the story may have been adapted from a popular version of the book of Tobit,' 17 without further exploration of this idea.

Generally dated around 200 BC, 18 Tobit was apparently also a widespread and influential book. ${ }^{19}$ It

16'ob Tob 3,8.15; 6,13; 7,11 die Erzählung inspirierte, kann erwogen werden', Pesch, Markus, II.232. Van Iersel, Reading Mark (Edinburgh, 1989) 151, likens the two stories.

17Lane, Mark (Grand Rapids, 1974) 427.

${ }^{18}$ D.E. Gowan, Bridge Between the Testaments. A Reappraisal of Judaism from the Exile to the Birth of Christianity (Pittsburgh Theological Monographs 14; Pittsburgh: Pickwick, 1976) 354.

${ }^{19}$ 'One of the most widely read books of pious fiction among ancient Jews,' holding 'a position in Jewish households similar to that once 
contains the story of Sarah, who is afflicted with a demon, a 'monster of the bridal chamber' ${ }^{20}$ By the time the hero, Tobias, sets his intentions upon marrying her, seven of her husbands have already been killed on their wedding night (Tob. 3:8-9, $6: 13-15,7: 11)$. Although this story has immediate contact with that of the Sadducees in that both concern the sevenfold loss of a woman's husbands, it also appears at first glance to have several differences: the Sadducees' tale spoke of 'brothers', assumed the context of Levirate marriage, and ridiculed the notion of resurrection, all of which seem fairly remote from Sarah's tale. However, a closer inspection also reveals closer connections.

\section{Levirate Marriage and 'Brothers'}

Tobit is a tale that assumes and illustrates the Levirate marriage practice. In fact, the book is dominated by this concern. One of the vehicles used to convey this important

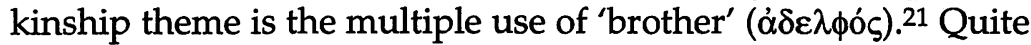
clearly in the book this word is used more broadly than for brothers-from-the-same-mother.

held by Bunyan's Pilgrim's Progress in our own,' Metzger, Introduction, 31, 40. He does not provide the evidence for these statements.

${ }^{20}$ Although this title is that of the folklorists Aarne-Thompson (Type 507B), whose classification is adopted by F. Zimmermann, The Book of Tobit. An English Translation with Introduction and Commentary (Dropsie College Jewish Apocryphal Literature; New York: Harper, 1958) 5-12, and P. Deselaers, Das Buch Tobit. Studien zu seiner Entstehung, Komposition und Theologie (Göttingen: Vandenhoeck und Ruprecht, 1982) 281-92, it is used here descriptively and merely for convenience without implying anything regarding underlying sources. For a critique of an uncritical use of the Aarne-Thompson classification see W. Soll, 'Tobit and Folklore Studies, with Emphasis on Propp's Morphology', in SBL Seminar 1988 Papers (D.J. Lull, ed.; Atlanta: Scholars, 1988) 39-53; 'Misfortune and Exile in Tobit: The Juncture of a Fairy Tale Source and Deuteronomic Theology', CBQ 51 (1989) 209-231. ${ }^{21}$ Across the two texts (S, BA) there are 54 uses of $\dot{\alpha} \delta \varepsilon \lambda \phi o ́ c: 1: 3,5 \mathrm{~S}, 10$, $14,16,21 ; 2: 2,3 \mathrm{~S}, 10 \mathrm{~S} ; 3: 15 ; 4: 12,13,13 ; 5: 5 \mathrm{~S}, 6,8 \mathrm{~S}, 9 \mathrm{~S}, 10,10 \mathrm{~S}, 11 \mathrm{~S}, 12$, $12,13,13 \mathrm{~S}, 13,13,13,15 \mathrm{~S}, 16 \mathrm{~S} ; 6: 6,10,12 \mathrm{~S}, 12 \mathrm{~S}, 13,15,17 \mathrm{~S} ; 7: 1 \mathrm{~S}, 1 \mathrm{~S}, 1$ S, $2 \mathrm{~S}, 3,4,7 \mathrm{~S}, 8,10 \mathrm{~S}, 11 \mathrm{~S}, 12 ; 9: 2,10: 6 \mathrm{~S}, 13,11: 2,17 ; 14: 4,7$. Cf. the congruent uses of $\dot{\alpha} \delta \varepsilon \lambda \phi \eta \dot{~ d i s c u s s e d ~ b e l o w . ~}$ 
The two major tasks that drive the plot of the story are the need to save Tobit from his blindness and Sarah from the childlessness caused by her demonic oppression. To achieve these goals, Tobias must marry within his kin. Tobit, who tells the reader that he married 'Anna, a woman of the stock of our

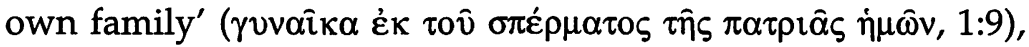
warns his son of the need to marry likewise within the family, following the precedent of Noah and the patriarchs (4:12 BA). The angel Raphael, disguised as a kinsman himself, later reminds Tobias of this responsibility (6:15).

Meanwhile, Sarah's problem is clearly presented as having no child, and no potential 'near kinsman' ( $\dot{\alpha} \delta \varepsilon \lambda \phi o ̀ s$ $\dot{\varepsilon} \gamma \gamma \cup$ s, 3:15) to redeem her. We first hear of her affliction when she suffers the abuse of one of her father's servant girls. The narrator tells us she had to endure this humiliation

for she had been married to seven husbands, and Asmodeus, the Evil Demon, had killed them off before they had been with her as is appointed for women (Tob. 3:8a).

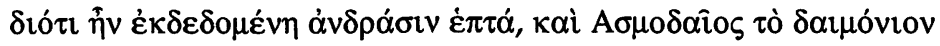

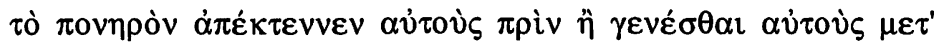

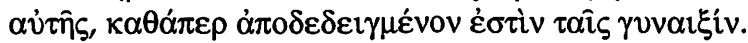

Zimmermann comments that the seven is probably a symbolic number, illustrating 'the hopelessness of Sarah's status. She was completely at the mercy of Asmodeus.'22 He comments further:

In the later rabbinic thought, a woman who had buried three husbands was called a qatlanit 23 as if there were something in her that was man-killing. Cf. Yeb. 64b: if a woman is married to one husband, and he dies; to a second, and he dies; she should not be married to a third. Such is the opinion of $R$. Judah. R. Simon ben Gamaliel avers, 'She may be married to a third, but not married to a fourth.' R. Huna declares 'The source is the cause' i.e., such is the nature of this woman. $R$. Ashi says, 'It is her evil fortune.'

22Zimmermann, Tobit, 62; cf. Is. 4:1.

23[i.e. one who kills]. 
Returning to the story: the words of the servant girl are then reported, as follows:

You are the one who kills off your husbands! Behold, you have been wedded to seven husbands, and you have not borne the name of one of them. Why do you vex us for husbands of yours, because they died? Go with them! So we won't ever see a son or daughter of yours! (Tob. 3:8b-9, Zimmermann).

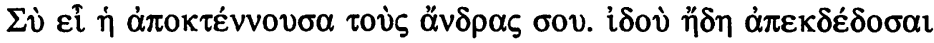

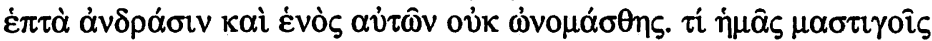

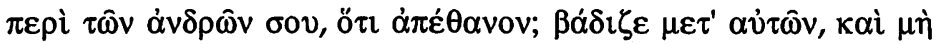

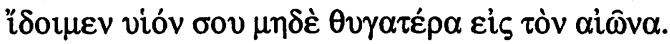

Instead of 'not [bearing] the name' meaning that the woman has not been married, ${ }^{24}$ it seems better to understand this in connection with the real problem of the story: she is a widow who needs redemption so that seed may be raised up for her dead husband(s), i.e. seven have died without children-there appears to be no hope that their name will live on ( $c f$. Dt. 25:6, 7).

Tobias, her potential rescuer, is cast as a kinsmanredeemer. Raphael tells him

you are her nearest-than-all-men to inherit her, and to legitimately inherit the things belonging to her father.

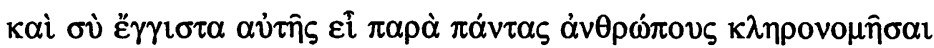

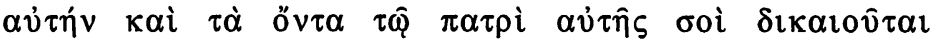
$\kappa \lambda \eta \rho о v o \mu \eta \hat{\sigma} \sigma{ }^{2} .25$ (6:12 S, cf. also 6:13).

\section{Zimmermann comments}

The Gk. strikingly 'to inherit her' because of the gradual disclosure that Tobias is obligated to marry Sarah because he is the surviving kinsman, and as levir, for such he is,

\footnotetext{
24Zimmermann, Tobit, 63, referring to Is. $4: 1$ and the practice of a wife carrying the husband's name, e.g. Judg. 4:17.

${ }^{25}$ The other text focuses only upon him inheriting what will come to

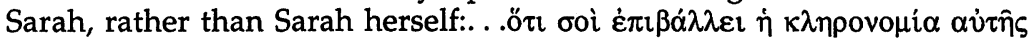
(6:12 BA).
} 
according to the conception of his function in Tobit, he is duty-bound to marry her and no one else. [...] We now see the poignancy of Sarah's plight. Her past seems black without redemption, and her future without hope. She has killed off seven husbands, and there is no surviving levir (apparently) to marry her. [. . .cf.] (6:15). Tobias accordingly appears in the role of a double rescuer. He not only saves her from the demon, but in his person as a levir, he is the only living surviving kinsman who can 'inherit' her to marry her. Were she to be married to another man aside from Tobias, she would be guilty of zenunim, a violation of the law of Moses and punishable by death. ${ }^{26}$ [cf. 6:13]

Tobias himself recognises his status when he expresses his concern to Raphael, having heard of Sarah's ailment:

"Brother Azariah, I have heard that the maiden was already given to seven men, but they died in the marriage chamber. The very night they went in to her, they died. Moreover, I have heard people say that a demon slays them. Now then, I am an only child to my father, and I am afraid were I to go in, I would die just as the previous ones, because he does not

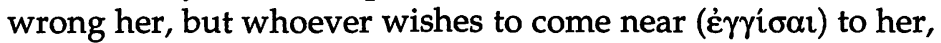
he kills him." (Tob. 6:14-15)

The last phrase is not in the BA text preferred by Zimmermann at this point. ${ }^{27}$ However, given the importance of the kinsman redeemer motif in the Book of Tobit, the $S$ text makes good sense as well as providing a vocabulary link with this motif

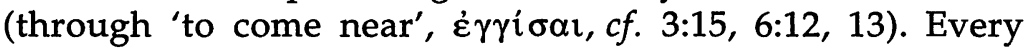
person who has attempted 'to come near' to her, i.e. every

26Zimmermann, Tobit, 82-83. The point can be taken even though 'to inherit her' may simply mean to inherit what is hers, as the same phrase clearly means at 3:15, and as the BA text evidently takes it (see previous note).

27Zimmermann, Tobit, 155, suggests v. 15 has suffered dislocation in the $S$ text and so takes over the BA text bodily. However, the principle of the more difficult reading would endorse the $S$ reading with its internal parenthesis. The parenthesis then explains the reasons for Tobias' fear, and the main sentence reveals the content of his fear, namely, that his own line would be snuffed out with him. Ultimately, however, both readings are patent of the interpretation offered here. 
person who has attempted to redeem her, has been killed. Asmodeus is cast as the one who kills the kinsman redeemer. The demon is directly antagonistic to the furtherance of Sarah's line.

Tobias is contemplating acting as a kinsman redeemer, where others have failed in the very process of fulfilling their kinsman redeemer's role. This catches him between two responsibilities: since he is an only son, to redeem his kinsman's name through Sarah will be at the risk of losing his own father's name! This is his great fear. This is confirmed by the narrator's comment that Tobias was comforted when he heard that 'she is to him a sister from the seed of his father's house'

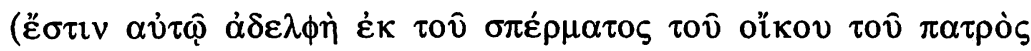
$\alpha \dot{\tau} \tau 0 \hat{v}, 6: 19)$. Thus strengthened, Tobias sets his mind upon having her as his wife, despite her problems.

The kinship theme is also present when Tobias stresses that he does not take Sarah, his sister, out of $\pi$ opvei $\alpha$ (8:7). Rather than meaning that he does not act out of 'lust', as it is usually taken ( $c f$. NEB), this ought to be understood in terms of Tobias' commitment to not taking someone from a prohibited degree, ${ }^{28}$ i.e. outside the kinship ties. ${ }^{29}$ This is confirmed by the clear contrast drawn by Tobit between $\pi$ opvei $\alpha$ and the taking of a wife within kinship ties (4:12 BA). On the wedding night, Tobias is rejoicing that he has done what his father has commanded (8:7). The fact that he embraces the possibility of his own death in order to fulfil this family obligation makes his action all the more noble when set against the norms of the story.

${ }^{28} \mathrm{Cf}$. Zimmermann's comment, (pp. 82-83, cited above) on Sarah's potential for being guilty of zenunim = adultery, Ho. 2:4 (LXX porneiva).

${ }^{29}$ Although the commentators do not discuss this possibility, this was certainly a usage in later times (cf. the discussion on the Rabbinics and on the apostolic decrees, Acts 15:20, 29, 21:25 in F. Hauck \& S. Schultz,

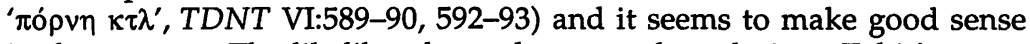
in this context. The likelihood may be strengthened given Tobit's stress on kinship marriage and faithfulness to God on the one hand, and the OT link between unfaithfulness and idolatry as harlotry on the other

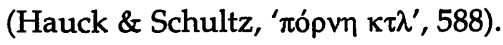


The book stresses Tobias' kinship with Sarah over and again. His fears were calmed and his love aroused by the news of their kinship (6:19 S). Like Tobit (5:21 BA, 10:6 S) and Raguel (7:15), Tobias calls his wife his 'sister' ( $\dot{\alpha} \delta \varepsilon \lambda \phi \eta$ ', $(7: 9 \mathrm{~S}, 8: 4,7) .30$ Raguel also calls Sarah Tobias' sister (7:12 S) and describes their marriage by saying 'from now on you are her brother and she is your sister' (7:12) and affirms that both he and Edna are parents to Tobias just as they are to 'his sister' (8:21 S). Edna calls Tobias her brother (10:13) and reiterates her husband's statement that from now on she is Tobias' mother and Sarah is his sister (10:13 S).

The kinship theme is also supported by the vocabulary of 'offspring' ( $\sigma \tau \varepsilon \dot{\varepsilon} \rho \alpha, 1: 1,9,4: 12 \mathrm{BA}, 6: 19 \mathrm{~S}, 8: 6,13: 17 \mathrm{~S}$ ) and 'name' (övo $\mu \alpha$ ). For the latter, Sarah is mocked for not bearing the name of seven husbands (3:8), yet she refuses to humiliate her father (3:10). She cannot raise a name through a child, but she has not besmirched her own name-through defiling herself with men-and she will not raise a name that humiliates her father through her suicide (3:11-15). Clearly, for her the only proper way to raise a name is through bearing a child. ${ }^{31}$

Thus, to sum up so far, the concern of the Sadducees' case study for brothers and Levirate marriage is exactly the same concern as that of the book of Tobit. In fact, since the loss of the seven 'brothers' in the context of Levirate practice is central to Tobit's story, an allusion to them would be an ideal way to evoke the entire message of the book. Is this what the Sadducees were doing?

\section{The Resurrection Question}

But what of the resurrection question, especially since some find no resurrection notion in Tobit? Nickelsburg, for example,

${ }^{30}$ Bow \& Nickelsburg suggest that this may be an implied comparison with Abraham's wife Sarah (Gn. 12:11-19). Note other parallels: their name; their childlessness; their confrontation with maids (Gn. 16:4, 6; cf. Tob. 3:7-9); their 'reproach' cf. barrenness (e.g. Gn. 30:23; Lk. 1:25); B. Bow, \& G.W.E. Nickelsburg, 'Patriarchy with a Twist: Men and Women in Tobit', in Levine (ed.), "Women", 139.

${ }^{31}$ Cf. 1:9 $\mathrm{S}$ where Tobit raises a name for himself in Tobias, and his desire to know Raphael's lineage and his name (5:12). 
argues that for Tobit, the traditional two-ways schema is used in the belief that one's reward is received in this lifetime, and death is when 'one descends permanently to Sheol, "the eternal place" $(3: 6,10){ }^{\prime} 32$ He contrasts this with the Epistle of Enoch which agrees that the righteous might descend to Sheol with grief (102:5), but overcomes the theodicy problem 'by positing a resurrection that will permit the kind of exchange in fortune that Tobit must experience before he dies (103:1-4).'33 He explains the importance of burial to Tobit in this light, since burial is the conclusion to one's life (Tob. 14:11-13, cf. 1 Enoch 103:5-8).

However, closer inspection reveals that Tobit has more to contribute to the resurrection question than first meets the eye. The Book is clearly concerned with the issue of bringing life where there was death.

(1) Tobit and Sarah. Tobit's practice of burying his dead brethren has a prominent place in the story (1:17ff.; 2:3 ff.). He understands the need for him to keep burying his countrymen in terms of Amos 8:10 (2:6): in exile even their feasting is continually interrupted with mourning. He risks his own death in order to bury the dead (2:8).

The burial of the dead leads directly to Tobit's blindness (2:9 ff.), which is itself regarded as a living death. As he puts it:

What joy can I have any more? I, a man without power of eyesight! I cannot see the light of heaven, but I lie in darkness like the dead who do not see the light any more. Living, I am among the dead! I hear the voice of men, yet I cannot see them $(5: 10){ }^{34}$

${ }^{32}$ G.W.E. Nickelsburg, 'Tobit and Enoch: Distant Cousins with a Recognizable Resemblance', Lull (ed.), 64. However, when Tobit prays that he might die, along with asking that he might become earth $(3: 6)$

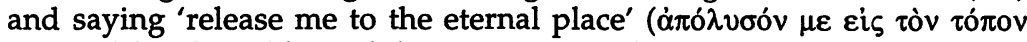
$\alpha i \omega ́ v i o v)$ he also adds 'and do not turn your face away, O Lord, from $\mathrm{me}^{\prime}$

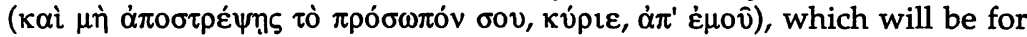
him a greater profit than to continue to live. This latter phrase throws into question whether the 'eternal place' is simply Sheol.

33Nickelsburg, 'Tobit and Enoch', 65.

${ }^{34}$ This would be reinforced if A.-J. Levine, 'Diaspora as Metaphor: Bodies and Boundaries in the Book of Tobit', Diaspora Jews and 
Sarah's problem is not only directly concerned with death through being a husband killer, but also indirectly-and perhaps more importantly in view of the concern of the book as a whole-in that she is unable to raise up seed to ensure her father's name continues in Israel. In this sense, she is death for her line. It is also possible that, just like Raguel faces the death penalty if he gives Sarah to any but Tobias (6:13), Sarah, too, faces it if she marries anyone other than a kinsman. ${ }^{35}$ Sarah's living death is brought out when her maids tell her to go with her dead husbands (3:8b-9).

In addition, Tobit and Sarah are both driven by their afflictions to cry out to the Lord that they might die, rather than continuing to be the 'living dead'. In this sense as well, when Tobias saves them, he is therefore bringing life to the (potentially) dead. Thus the completion of the two main tasks of the book are cast as the bringing of life where there was death.

(2) Tobias. Tobias' journey is begun because of Tobit's desire for death $(4: 1-2)$, and is shrouded with death since he is charged to bury his parents properly (4:3-4). When he is sent on his journey by his father, Anna thinks he has gone to his death and so she mourns him, as someone who mourns her only son (10:7, cf. Am. 8:10).

There are overtones of death in Raguel's exhortation

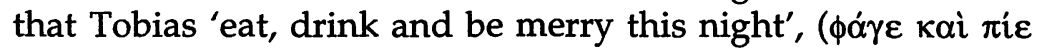

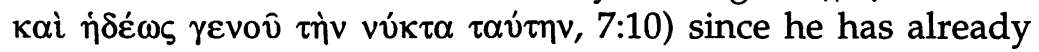
seen seven die on the night of the wedding (7:11). His exhortation is reminiscent of a proverbial phrase which set these three elements against the backdrop of a certain (and often imminent) death. The proverb not only had a widespread and long-lasting currency in the ancient world, 36 but was also

Judaism. Essays in Honor of, and in Dialogue with, A. Thomas Kraabel (J. Overman, \& R. MacLennan, eds.; Atlanta: Scholars, 1992) 109, correctly associates blindness with a concern for the 'boundary' between, amongst other things, life and death.

${ }^{35}$ See the comments by Zimmermann referred to above.

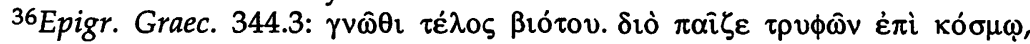
'know the end of life. Wherefore sport and revel on earth'. Herodotus, Hist. 2.78, tells of the Egyptian practice of carrying coffins into drinking bouts while proclaiming the words 'drink and make merry, but look 
represented in the Biblical tradition (Isa. 22:13). Given the proverbial nature of 'eat and drink and take pleasure', Tobit's exhortation would be readily completed by the hearer '. . for soon you will die'.

Raguel certainly holds little hope for Tobias' survival, as the story proceeds to show with its macabre scene of the grave being dug in the backyard while the newlyweds sleep inside the house (8:10-11). This further illustrates the nature of the task before Tobias. As Sarah's near relative he is obligated to marry her, but, at least in the mind of her father, this obligation will mean certain death. Like the righteous man Tobit went blind in order to bury his fellow Israelite, so too his righteous son will risk his own death in order to redeem his fellow Israelite's name. When they sit down to 'eat and drink' (7:14) the mood of the story is ominous. Her parents hold no hope and her bridal chamber is decked with tears $(7: 15-17 ; c f$. Am. 8:10). When the eating is complete, it seems like Tobias' death is even closer (8:1), so close that the grave must be dug (8:10). However, despite the ominous expectation of his death, we learn that he is saved (8:14) and God is praised for his mercy: Raguel's reproach has been removed, mercy and

on this; for such shalt thou be when thou art dead'. Euripides, Alc. 78089 , has Heracles proclaim: 'From all mankind the debt of death is due, nor of all mortals is there one that knows if through the coming morrow he shall live,...this hearing then, and learning it from me, make merry, drink: the life from day to day account thine own, all else in fortune's power'. Cf. the similar wisdom found in inscriptions on

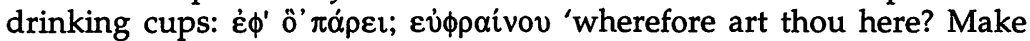
merry!', A. Deissmann, Light From the Ancient East (L.R.M. Strachan, transl.; ed. 4; London: Hodder \& Stoughton, 1927) 129-31. The phrase 'to eat and drink' was used to sum up the Epicurean philosophy by Plutarch (cf. non posse suaviter 1098C; 1100D; adv. Colotem 1125D) and others (cf. A. Malherbe, 'The Beasts at Ephesus', JBL 87 [1968] 76). The grave of the legendary Assyrian king, Sardanapal (cf. W. Röllig, 'Sardanapal', Der kleine Pauly 4:1550-51), who for the ancient world became the epitome of the Epicurean philosophy, apparently bore the inscription $\tilde{\varepsilon} \sigma \theta \imath \varepsilon, \pi \hat{\imath} v \varepsilon, \pi \alpha \hat{\imath} \zeta \varepsilon$ and possibly even went on to say 'knowing full well that thou art but mortal, indulge thy desire, find joy in thy feasts. Dead, thou shalt have no delight,' (Malherbe, 'Beasts', 7677); cf. Plutarch, Alex. fort. virt. 330F; 336C. है $\sigma \theta \imath \varepsilon, \pi \mathrm{i} v \varepsilon, \dot{\alpha} \phi \rho \circ \delta \imath \sigma i \alpha \zeta \varepsilon:$

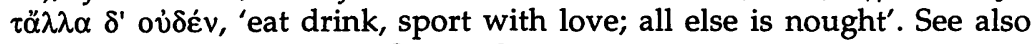
Horatius, Carm. 1.4; 2.3; 1 Cor 15:32. 
salvation have been shown to Tobias and Sarah (8:17)! In a very real sense, Tobias himself is delivered from death.

In addition to facing physical death, Tobias threatens to bring death to his line by marrying Sarah. He must go to the jaws of death in order to bring life, not only to Sarah's line, but to his own. If he does not succeed, his parents too will go to their graves in grief, and, what's more, with no-one to bury them (6:15). Couple this with Anna's fear that Tobias is dead (10:3ff.), and it becomes clear that Tobias not only raises his parents and Sarah from the dead in the course of the story, but is himself 'raised from the dead'.

Thus as the story unfolds, Tobias rescues his parents from the death of their line and the prospect of a death without burial; Tobit from the living death of blindness; Sarah and her household from the demon of death that brought death to their line; and Raguel from the potential death penalty for giving his daughter to someone else; and all this through being rescued from death himself.

(3) The Ethical Teaching. The ethical teaching of the book, especially that on alms-giving, has often been regarded as an important indicator of the book's purpose. However, it ought to be recognised that even this ethical teaching is set within a 'resurrection' context. For example, Tobit tells Tobias that as a person gives alms, 'you store up a good credit for yourself against the day of necessity. For alms deliver from death, and allow not descent to Darkness,' (4:9-10). This is reinforced by the angel Raphael who avers that almsgiving not only purges away sin, leading to life to the full, but also delivers from death $(12: 9) .37$

37In fact, the entire 'moral' section may express more of an eschatological outlook than is usually recognised, $c f$. the promise of reward from the Lord (4:14) vs. the Lord humbling to Hades below (4:19). This perspective is hinted at elsewhere: e.g. they are to bless God into eternity (12:17); 'blessed be the living God into eternity and his kingdom!' (13:1); 'He chastises, then shows mercy; He leads down to Hades below the earth, but He delivers from the great destruction $(13: 2)^{\prime}$. 
(4) Tobit and the Greek Reader. Tobit was most probably directed toward an audience familiar to some degree with Greek culture. As Di Lella puts it:

[Tobit] is nomic literature in narrative form that gave meaning and hope to Jews living in the confused and confusing society of Hellenistic times. The pervasive and spiritually pernicious impact of Hellenism was being felt even by pious believers [through] the beauty and modernity of Hellenistic culture and art, of customs and religion.38

For such readers Tobit's association with 'resurrection' would be enhanced by the similarities it shares with the Greek Legend of Admetus, which Glasson proposed to be its source. ${ }^{39}$ The story not only tells of Admetus entering the bridal chamber of Alcestis to find the snakes of Artemis in the marriage chamber, but apparently also portrayed Alcestis voluntarily dying to rescue Admetus from death, and subsequently being sent back from the underworld (Apollodorus, Library I.ix.15).

(5) The Theological Purpose of Tobit. Thus the internal workings of the story show quite a concern with 'resurrection', even if this resurrection is symbolic or metaphorical, rather than physical or actual. But there is still more to say on this theme. Not only is this concern evident in the internal dynamics of the story, but when the overall purpose of the book of Tobit is set within its theological context, it becomes clear that this 'resurrection' theme is profoundly important to the message of the book. 40

i. Tobit's Theological Purpose. Most scholars agree that Tobit has a setting in the eastern Diaspora. ${ }^{41}$ Although many find the

${ }^{38}$ A. Di Lella, 'The Deuteronomistic Background of the Farewell Discourse in Tobit 14:3-11', CBQ 41 (1979) 388.

${ }^{39}$ T.F. Glasson, 'The Main Source of Tobit', ZAW 71 (1959) 275-77.

${ }^{40} \mathrm{This}$ article therefore endorses the recent trends which attempt 'to tie more closely the message of the book to its overall structure,' R. Doran, 'Narrative Literature', Early Judaism and Its Modern Interpreters (R.A. Kraft \& G.W.E. Nickelsburg, eds.; Philadelphia \& Atlanta: Fortress \& Scholars, 1986) 298, through proposing a more theological understanding of the book's message.

${ }^{41}$ The options are summarised by Doran, 'Literature', 299: Eastern diaspora: Lebram, Grintz, Nickelsburg; Antioch: Zimmermann; 
historicity of its contents suspect, it is nevertheless agreed that 'the book does have another kind of historical value as a testimony to the way Judaism responded to the realities of life in the Diaspora.' 42 This response is often discussed merely in terms of 'dispersion ideals', 43 or pious behaviour, as evidenced by the various purposes suggested for Tobit (see below). However, it should not be forgotten that one of the ways Judaism 'responded to the realities of life in the Diaspora' was to respond theologically, 44 that is, to rely on, to reiterate and to build upon the hopes erected by her prophetic heritage. It is against this theological context that Tobit ought to be understood.

It is more than a 'sapiential story' merely being interested in 'proper human behaviour' ${ }^{45}$ It is not simply

intended to provide religious and moral instruction in the form of an adventure story. The chief lesson which it conveys is that God in his mysterious providence, though permitting various calamities to befall those who are righteous, at the same time exercises a special care over them in the midst of their sufferings and grants them a happy ending to all their trials. 46

Nor does it simply intend

to tell, through the misfortune and eventual redemption of Tobit and the adventures of his son in finding a bride in

Samaria and Galilee: Milik; Jerusalem: R.H. Pfeiffer; Alexandria, expanded in Jerusalem, then again in Alexandria, then finally Jerusalem: Deselaers.

42Gowan, Bridge, 354.

43Metzger, Introduction, 37.

44'For some Jews of the postbiblical period the Dispersion continued to be a theological problem, and a massive return from the Dispersion, often portrayed in the language of Second and Third Isaiah, became a standard item in descriptions of the end-time,' G.W.E. Nickelsburg, Jewish Literature Between the Bible and the Mishnah. A Historical and Literary Introduction (Philadelphia: Fortress, 1981) 17.

${ }^{45}$ Nickelsburg, 'Tobit and Enoch', 62.

${ }^{46}$ Metzger, Introduction, 31. 
Media, how piety and faithfulness to the God of Israel enable one to triumph over ills both natural and supernatural. ${ }^{47}$

Although it is true, with Glasson, to say that the story is primarily about the marriage of Tobias and Sarah and the overcoming of the demon, ${ }^{48}$ this also needs to be set in the wider theological context of the book.

Deselaers, concentrating on the terms hodos, eleemosynai, eulogein, argues that these terms have sociological implications bound up with maintaining the family, kin, and people together as well as being related to God's dealings. From this he draws the conclusion that the author is stressing that there is no barrier between humanity and God.49 But these data need to be placed in a more profound theological context, and any theological statements arising from them should not be cast in such general terms, but should be shaped by the prophetic heritage of Israel.

This appropriate theological context is approached most closely by Nickelsburg, who regards the teaching of that which constitutes a pious life as only a secondary purpose. After noting the movement from piety to blessing, he states that the primary purpose of the work is to assure its readers that God is with them even in dispersion and that he will bring them back together. 50 In other words, Tobit encourages its readers to believe that the hopes of the prophets would be fulfilled (14:4, cf. 15). He does this explicitly (14:4), stating that the exile will cease one day (14:5) and the nations will turn from their idolatry (14:6); but he also does it in story form, illustrating that the nation that is theologically dead will one day be raised from the dead.

ii. Tobit and the Exile. Although questions have been raised about the originality of the last two chapters, a good number of

47Gowan, Bridge, 353.

48Glasson, 'Source', 275-77.

${ }^{49}$ As summarized by Doran, 'Literature', 298.

${ }^{50}$ G.W.E. Nickelsburg, 'Stories of Biblical and Early Post-Biblical Times', Jewish Writings of the Second Temple Period: Apocrypha, Pseudepigrapha, Qumran, Sectarian Writings, Philo, Josephus (M.E. Stone, ed.; Philadelphia: Fortress, 1984) 33-87. 
scholars support the book's unity. ${ }^{51}$ These last chapters help to anchor the story of the book in the theological life-setting for which it has relevance.

When we notice that the exile is the enduring misfortune underlying the particular misfortunes that are resolved in the Tobit narrative, the unity of the work impresses itself more forcibly on us. [. . .] chaps. 13-14 are not merely tacked on, but are necessary in view of the way the author has portrayed the initial situation as one of exile and has explicitly connected the villainies or lacks that befall the Tobit family to that exile. It is in these last chapters that the prospect of an end to that exile is held out. 52

Despite the narrative setting of the book being the Assyrian dispersion, and the fact that Nineveh 'is sufficiently remote in time to serve as a symbol for the current exilic situation anywhere in the diaspora', 53 these final chapters reveal that this setting is used as a vehicle to picture the situation which prevailed for Israel after the Babylonian exile:54

the fate of the nation is of great concern to the author of Tobit, and he speaks almost exclusively of it in the last two chapters, [which] suggests that the author's application of it to Tobit's own suffering is secondary and that the problem of Exile and Dispersion and the hope for a regathering of the people are foremost in his mind. This return from Dispersion will have as its focus proper pan-Israelite worship in a Jerusalem rebuilt according to the promises of Isaiah 54 and 60 (13:9-18; 14:5). In his testamentary forecast (14:4-7) Tobit envisages the Babylonian Exile, the Return, the rebuilding of

${ }^{51}$ Gowan, Bridge, 354. Zimmermann is in the minority, arguing that 13 and 14 were later additions. However, the presence of all 14 chapters at Qumran discredits some of his arguments; Doran, 'Literature', 297.

52Soll, 'Misfortune', 230.

53Soll, 'Misfortune', 230. He refers to the work of J. Lebram and D. Flusser who isolate the sequence of kingdoms in Tobit as a rudimentary form of what became the four empires motif in Daniel.

${ }^{54}$ This may gain extra support if Torrey is right that at the time of writing Nineveh was identified with Seleucia ( $c f$. 'Ashur is Seleucia', Yoma 10 a; Kethuboth 10 b), and the writer was a Babylonian Jew, C.C.

Torrey, "Nineveh" in the Book of Tobit', JBL 41 (1922) 243-45. 
the Temple, and then in the end-time the rebuilding of a glorious Jerusalem and the conversion of the Gentiles. 55

The writer of Tobit evidently applied Israel's theological heritage to his own situation. Several studies have identified Deuteronomistic influence in Tobit, 56 claiming 'that the author...shared many of the same intentions of the final redactors of Deuteronomy, viz., encouragement of the depressed people and exhortation to remain true to the faith,'57 and that the Deuteronomic theology is invoked to interpret the situation of exile. ${ }^{58}$ Tobit's author was 'a perceptive student of Israel's ancient heritage' who employed the Deuteronomistic theology of history to show that the disasters of the nation were due to the people's infidelity 59 which lead them into idolatry. That he draws upon the theological heritage of the prophets is also fairly obvious.

The elements of Tobit's narrative are explicitly cast against this exilic situation. Tobit himself may represent Israel in temporary exile.60 When he prays for death he catches himself up in the exile (3:4), identifying himself with wayward Israel, even though personally innocent.61 When the exilic prophets spoke of Israel's plight they used a conventional description of the unfaithful community 62 by referring to Israel's blindness. Israel is blind (Is. 35:5, 41:7, 18-22), not only because he has not listened to his God, but because he has served other gods (Is. 44:9, 18). Israel's blindness is thus linked with his idolatry. As for Tobit, he recognises Israel as idolatrous and himself as innocent (chap. 1), and yet he is so caught up in the exile of his people that he too becomes blind.

55Nickelsburg, Jewish Literature, 33-34, referring to 3:4-5, 13:2, 5, 9; 13:14; 14:5 cf. Ps. 89:32-34; Ps. Sol. 7:8-10; 10:1-4; 18:4-7; Wis. 12:22.

56Di Lella, 'Background'; Soll, 'Misfortune'.

57Di Lella, 'Background', 380-81.

58Soll, 'Misfortune', 221.

${ }^{59} \mathrm{Di}$ Lella, 'Background', 388.

${ }^{60}$ Levine, 'Diaspora', 113-14. In particular, she interprets the theme of uncleanness against this backdrop, with Nowell's unpublished dissertation.

61Soll, 'Misfortune', 224.

62Levine, 'Diaspora', 113. 
On the other hand, just like the prophets promised that God would make blind Israel see once again (e.g. Is. 35:5, 42:7), so Tobit finds salvation through the restoration of his sight.

Sarah's prayer likewise refers to her exile (3:15), and Soll speculates how Sarah's demonic affliction may also be associated with exile:

Polytheism presumed the local jurisdiction of gods; some Jews may have retained this notion in regard to demons. It is plausible that the author of Tobit thought that exile made Jewish young women vulnerable to evils of this kind.63

Levine builds upon this speculation to say that 'Sarah represents what could be [the covenant community's] fate in the diaspora: ignorant, childless and in the undesired embrace of idolatry represented by a demon.' 64

However, the link may be even more profound. The LXX forges an integral link between the idolatry that caused Israel's exile and the demonic. This was a link which was perfectly obvious to the Greek world-in fact, necessary, since the gods must keep their distance from this world and it was therefore right that the intermediate beings, (i.e. the 'daemons') serviced the idols instead of them.65 The LXX, written for this world, on several occasions, sometimes even extending the MT, associates Israel's idolatry with demonic worship (Dt. 32:16-17;66 Pss. 96 [LXX 95]:5; 106 [LXX 105]:3738; Is. 65:3,67 11) and directly links the exile with this demonic worship (Dt. 32; Ps. 106 [LXX 105], ?Is. 65).

This connection between idolatry and the demons is continued in later Jewish writings, as is the connection between this demonic worship and the exile. So, for example, in Baruch,

63Soll, 'Misfortune', 225.

64Levine, 'Diaspora', 112.

65See for example, the classic discussion by Plutarch in De defectu. Paul was well aware of this connection (1 Cor. 10:20-21).

66The Greek translator chooses not to render the Hebrew (which would require a relative clause), but instead makes the verse present a starker alternative: they sacrifice 'to the demonic [spirits], not to God'.

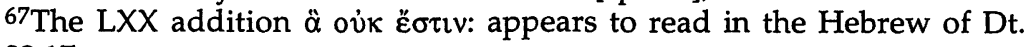
32:17. 
which is itself an appeal for an end to exile (2:11ff., 3:1-8), both Israel's dead and living share in the guilt which caused the exile (3:3-4) and, consequently the living have been numbered with those that lie in the grave (3:10-11). This guilt was due to Israel, through sacrificing to foreign gods, sacrificing to demons (Ba. 4:7).68 The promise is given that the exiles will return, leaving Babylon to her demons (4:27-37). (See further, 1 Enoch 19:1, Jub. 11:4ff.).

In view of this background, Sarah's affliction could well picture the exiles, not as being 'in the undesired embrace of idolatry represented by a demon,' 69 but as being afflicted with the demon of death as a consequence of their own worship of demons in the first place. ${ }^{70}$

And, of course, the notion that the exile is the death of Israel is also prevalent in the prophetic material, out of which the image of the 'resurrection' of the nation develops. Thus Ezekiel 37 portrays the exile and return metaphorically in terms of death and resurrection of the bones of the people of Israel. This would subsequently take on a much more literal expectation in the writings of Daniel (Dn. 12) and beyond. The writer of Tobit therefore has good prophetic precedent for constructing a story which makes such major use of the 'resurrection' metaphor.71

68 J.C. Dancy, The Shorter Books of the Apocrypha (СВC; Cambridge: Cambridge University Press, 1972) 193 . The similarity of Ba. $4: 7$ with Is. 65:3 is evident, as is the fact that the latter portion quotes directly Dt. 32:17 (LXX). D.G. Burke, The Poetry of Baruch (S\&CS 10; Chico: Scholars, 1982) 158, points out that Ps. 106:37 makes it clear that it is not sacrifice in general but child sacrifice that is meant in all three verses.

${ }^{69}$ Levine, 'Diaspora', 112.

${ }^{70}$ This is a constant theme of the OT (e.g. Judg. 10:11-14); cf. Paul's argument in Romans 1, where people are given up by God to the consequences of what they in their sinfulness have already turned to.

71Further examination of Tobit may reveal even more interest in a resurrection theme. For example, the notion of inheriting the land according to the Abrahamic promises is linked with the need for taking a wife from amongst the kinfolk (4:12 BA), and the return from exile (14:7, cf. Is. 51:2 and also Dt. 1:8, 6:10, 30:20, 34:4, cf. 9:5, with Di Lella, 'Background', 381-82) and may have been understood in terms of resurrection at this stage. This was no doubt the case in 2 Mac. 7, where the final brother 'recalls the Law of Moses, the covenant with Abraham 
Not only are blindness, demonic affliction and death associated with Israel's exilic plight, but so too is the notion of the kinsman redeemer who rescues him from that plight. The earlier notion of God as Israel's kinsman-redeemer (e.g. Ex. 15:13, Ps. 106:10) was taken up especially by the latter chapters of Isaiah. ${ }^{2}$ God is Israel's near relative (44:14, $47: 4$ etc), and he will redeem Israel from the exile (43:1, 44:22-23, 52:9 etc.). In this way, the hope is generated that the Exile will be reversed by God once again playing his role as kinsman redeemer. In the theology of Isaiah, this rescue will come through the death and resurrection of the Servant of the Lord, cf. Tobias who embraces his (potential) death in order to redeem and is rescued from it. 73

Thus, not only can the misfortunes of the book 'be seen as acute manifestations of the chronic condition of exile, 74 but their resolution can also be seen as the reinforcement of the hopes generated by the exilic prophets that the exile would one day be reversed. Thus, the statements of the final chapters do no more than make explicit what is implicitly, but powerfully taught by the symbolism of the 'fairy story'; the two elements of the book thus working together in a harmonious unity. At the symbolic level, the fairy story does provide 'the ultimate model for the resolution of evil', ${ }^{75}$ for, by uniting the Deuteronomistic concern for 'life and death' (cf. Dt. 30:19-20) ${ }^{76}$ with the

and the promise of resurrection which by now it is understood to entail,' Young, 72; $c f$. the later 4 Mac. 13:17, Romans 4.

72R.C. Denton, 'Redeem, etc.', IDB 4:21-22.

73Interestingly, the book of Job links God as redeemer with the resurrection (Job 19:25). Although I haven't explored this any further, comparisons have been regularly drawn between Tobit and Job, see Levine, 'Diaspora', 113; Soll, 'Misfortune', 224; Nickelsburg, Jewish Literature, 33.

${ }^{74}$ Soll, 'Misfortune', 222, 225.

${ }^{75} \mathrm{Cf}$. Soll, 'Misfortune', 230: 'For the author of Tobit and his audience in the Jewish diaspora, the fairy tale cannot provide the ultimate model for the resolution of evil. Yet the glimpse of joy it provides, and the implication that evil is not finally triumphant, makes the fairy tale a good kind of story to listen to, adapt, and tell while awaiting the destruction of "Nineveh"'.

76Di Lella, 'Background', 385-87. 
prophetic images and expectations, it models God's concern, as Israel's kinsman redeemer, to bring life from the dead.

(6) Tobit, the Exile and the Resurrection. Despite the return to the land under Cyrus' patronage, it is clear that many considered that Israel was still in exile. In this theological setting, the book of Tobit is an example of a narrative which seeks to maintain the 'resurrection' hope of the prophets. Like Tobit (3:6, cf. 2:11-14) and Sarah (3:7-15, 8:10-11), exiled Israel may be suffering the reproaches of others (Tob. 3:4, Dt. 28:3, 1 Ki. 9:7),77 but one day these will be gone. Like Tobit, Israel may be blind, but one day he will see. Like Sarah, Israel may be subject to a demon of death, but one day he will live again. Like Tobias, there will be a kinsman redeemer who will come, prepared to enter into the death of Israel in order to achieve Israel's 'resurrection'. Through his narrative the writer of Tobit draws upon Israel's theological heritage in order to maintain and encourage the expectation that God, the great kinsman redeemer, would bring a return from exile, restore the blind, heal the demon afflicted and reverse her barrenness, yes, and even raise the dead. If the exile brought mourning instead of joy (Am. 8:10, cf. Tob. 2:6, 7:15-17, 10:7), the writer of Tobit, through the medium of the 'eucastrophic' (i.e. turning disaster to joy) fairy tale, aids the recovery of joy amongst his contemporaries by the reinforcement of the hope of 'resurrection'.78

\section{Return to the Sadducees' Question}

It has become clear, then, that the stories of the seven brothers in the book of Tobit and the Sadducees' case study are much closer than at first sight. The suggestion of Pesch and Lane has been fruitfully pursued to a conclusion: the Sadducees are quite

${ }^{77} C$ f. Soll, 'Misfortune', 226-28.

78Soll, 'Misfortune', 229. The importance of joy to the story (cf. 5:10, 11:15) has often been noticed. 
probably primarily referring to the book of Tobit.79 If so, what does this identification of their reading matter entail?

At the very least, it follows that there is no need to insist that the brothers in the Sadducees' case study need to be brothers from the same mother (as in 2 Mac. 7, for example). This should not be a great surprise, since Deuteronomy 25 itself allows for this wider understanding of the brother who acts as a levir, but Tobit provides confirmation. The Sadducees' case study may well be talking of seven brother Israelites, or seven brothers from the same tribe, rather than brothers from the same mother.

But given the allusion, still more can be said. If the Sadducees are alluding to Tobit, does this mean that the Pharisees discussed this particular story, not so much in terms of its implications for levirate law, but in terms of its implications for the resurrection hope that its message perpetuates? The Sadducees can then pick it up as, in their terms, a self-contradictory story, for how can the resurrection belief it encourages be held alongside the Levirate practice it illustrates?

It also seems logical that it would be the hope of the resurrection of Israel that is under discussion. 80 The Sadducees, as the politically advantaged, perhaps had no need of such hopes, especially if they were drawn from non-Mosaic teaching and reinforced by such contradictory case studies as that of Tobit. For the Pharisees, however, such hopes were a crucial part of their prophetic heritage and any rejection of

\footnotetext{
${ }^{79}$ Even if Tobit is the primary reference, it may be that the connotations are enriched by the Maccabean martyrs also being evoked. The reference to 'seven brothers' brings both stories into the reader's repertoire. The connotations from 2 Mac. 7 import the notion of resurrection to the readers mind. As the Sadducees add the information regarding the loss of the husbands, it fixes the allusion to Tobit. However, since Tobit also concerns resurrection (albeit at the symbolic level), the associations connoted by the Maccabean martyrs are not dismissed entirely.

${ }^{80}$ This can be compared to the similar story of a bridegroom dying on the wedding night which is clearly linked to the death of the nation in exile (2 Esd. 9-10).
} 
them would deserve the kind of sharp rebuke that Jesus serves his opponents.

In addition, in view of the increasing recognition of the importance of intertextuality to the reading of a story, it is not enough simply to state that this is the background to the Sadducees' case study and take it no further. If it is, then their short allusion to the Tobit story will evoke much-or even all-of that story and it is therefore important to inquire after other features of the story that may be evoked and how such connotations, once recognised, nuance the reading of Mark. Mark shares many features in common with Tobit: both have characters who are blind, barren and demon-afflicted, and in both cases it could be said that these characters represent 'what could be [the covenant community's] fate in the diaspora: ignorant, childless and in the [...] embrace of idolatry represented by a demon.' 81 At the opening of Mark's story, Israel is still regarded as in exile; Israel is afflicted by demons; Israel is blind; Israel still awaits a kinsman redeemer and the fulfilment of the prophetic hopes of restoration and resurrection. If the Sadducees' case study evokes the story of Tobit, the question of what this adds to the repertoire of Mark's reader and so to the experience of reading Mark still awaits further fruitful exploration. 82

${ }^{81}$ Levine, 'Diaspora', 112, of Sarah. I have also removed 'undesired' from the citation for the reasons discussed above.

82This is the subject of part of my doctoral dissertation which is presently being researched at King's College, London. 